\title{
The most westward European occurrence point for Dreissena bugensis (Andrusov 1897)
}

\author{
OANa Paula PoPA ${ }^{1} \&$ LUIS Ovidiu PoPa ${ }^{1}$ \\ 1 "Grigore Antipa" National Museum of Natural History, Sos Kiseleff no.1 Bucharest, Romania e-mail: oppopa@antipa.ro, \\ popaluis@idilis.ro
}

\begin{abstract}
PoPA, O. P. \& PoPA, L. O., 2006: The most westward European occurrence point for Dreissena bugensis (Andrusov 1897). - Malacologica Bohemoslovaca 5: 3-5.

Online serial at $<$ http://mollusca.sav.sk $>16-$ February-2006.
\end{abstract}

The occurence of Dreissena bugensis (Andrusov 1897) from the Romanian Danube is reported. This represents the most westward occurrence point of quagga mussel in Europe.

Dreissena bugensis (quagga mussel, Fig. 2, 3) was found by Andrusov in 1890 in a narrow region of the Bug river. The species remained in its natural range until 1940, when it began to spread in the Ponto-Azov basin (ZHulidov et al. 2004). Later (1940-1990) D. bugensis started to spread to the north of the Black Sea, Dnjepr river and Volga basin. (ZHULIDOV et al. 2005, ORLOVA et al. 2004). Apparently the species is absent from Western Europe, but it was found in the Great Lakes in North America, in 1989 (MAY \& MARSDEN 1992).

The presence of the species in the river tributaries to the Black Sea was considered to be possible, but no evidence was found to prove it. In Romania, the species was found for the first time at Cernavoda $\left(44^{\circ} 21^{\prime} \mathrm{N}, 28^{\circ} 02^{\prime} \mathrm{E}\right)$ in the Danube river in 2004 , at depths ranging from 0 to $5 \mathrm{~m}$ below the water surface, on concrete aquatic structures (MICU \& TELEMBICI 2004).

Locality and material examined: SW Romania, Drobeta Turnu Severin (44\%37'13.68"N, $\left.22^{\circ} 40^{\prime} 49.40^{\prime \prime}\right)$, in an abandoned fishing net on the bottom of the Danube river, August 23, 2005, 20 living adult specimens, L. Popa leg., O. Popa det. This is the second finding of the species in Romania and it represents the most westward occurrence point for the species D. bugensis in Europe. This finding documents the range expansion of the quagga mussel, and it's worth mentioning that the Rhine-Main-Danube Canal offers no physical barrier to the spreading of this invasive species to Western Europe. (MÛ́LLER et al. 2002).

Acknowledgement: This study was partially supported by the Romanian Academy grant no. 69/2005 allotted to L.O.P. The authors thank Peter L. Reischütz for helpful comments on the manuscript.

\section{References}

MAy B. \& MARSDEN J. E., 1992: Genetic identification and implications of another invasive species of dreissenid mussel in the Great Lakes. - Can. J. Fish. Aquat. Sci. 49: 1501-1506.

Micu D. \& Telembici A., 2004: First record of Dreissena bugensis (Andrussov 1897) from the Romanian stretch of River Danube. In: Abstracts: International Symposium of Malacology, August 19-22 ${ }^{\text {nd }} 2004$, Sibiu, Romania.

Müller J. C., Hidde D. \& SeItz A., 2002: Canal construction destroys the barrier between major European invasion lineages of the zebra mussel. - The Royal Society 269 (1496): 1139-1142.

Orlova M. I., Muirhead J. R., Antonov P. I., ShCherbina G. K., Starobogatov Y. I., Biochino G. I., Therriault T. W. \& MACISAAC H. J., 2004: 
Range expansion of quagga mussels Dreissena rostriformis bugensis in the Volga River and Caspian Sea basin. - Aquatic Ecology 38: 561-573.

Zhulidov V. A., Zhulidov D. A., Pavlov D. F. NAlePa T. F. \& GuRTovayA T. Y., 2005: Expansion of the invasive bivalve mollusk Dreissena bugensis (quagga mussel) in the Don and Volga River Basin: Revisions based on archived speci- mens - Ecohydrology \& Hydrobiology, 5 (2):127133.

Zhulidov V. A., Pavlov D. F., NalePa T.F., SHCherBina G. H., Zhulidov D. A. \& GuRtovaya T. Y., 2004: Relative distributions of Dreissena bugensis and Dreissena polymorpha in the lower Don River System, Russia. - Internat. Rev. Hydrobiol., 89 (3): 326-333.

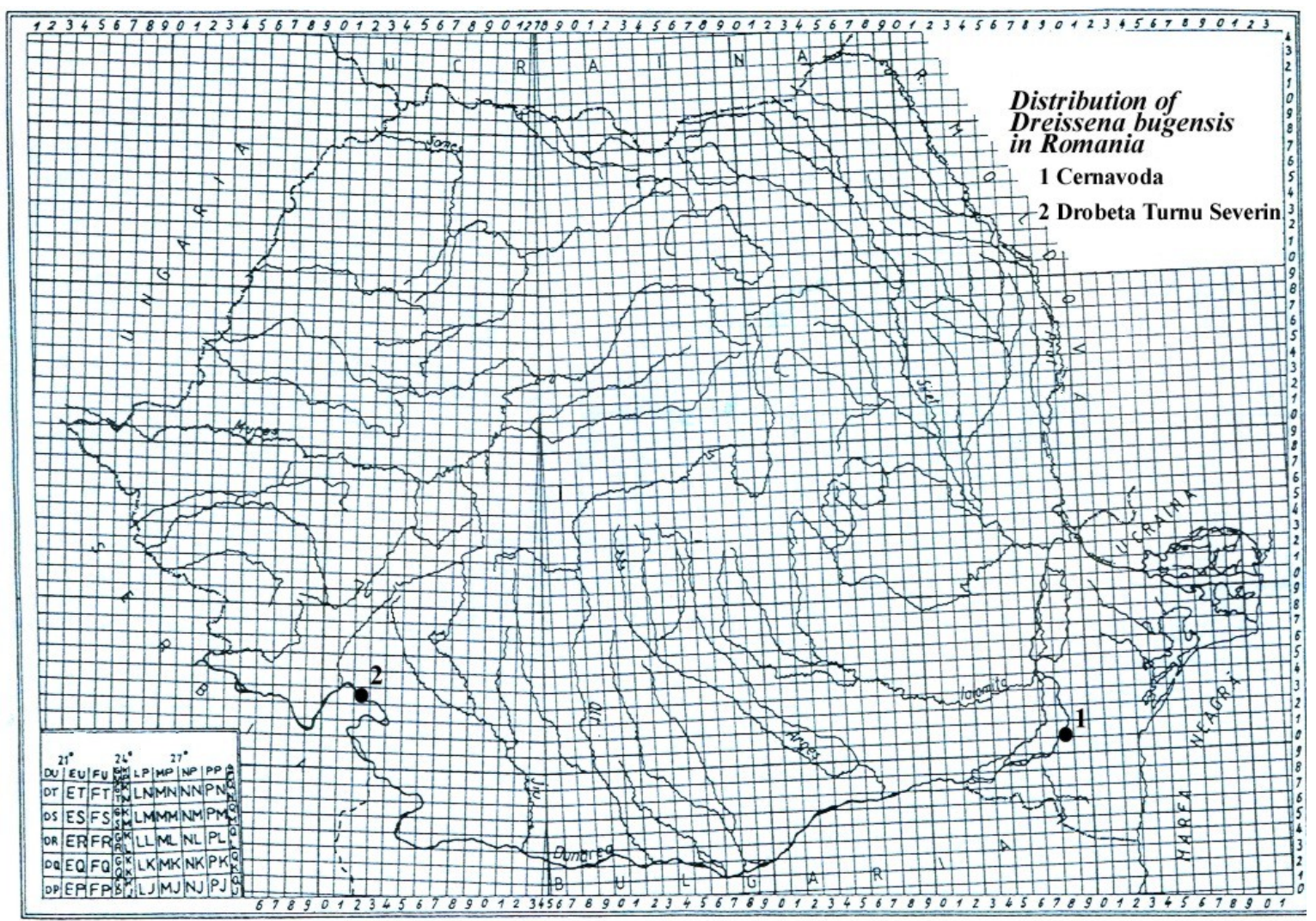

Fig. 1 The distribution of Dreissena bugensis in the Romanian sector of the Danube river. 1 - the first record in Romania; 2 - the most westward collection point of D. bugensis. 


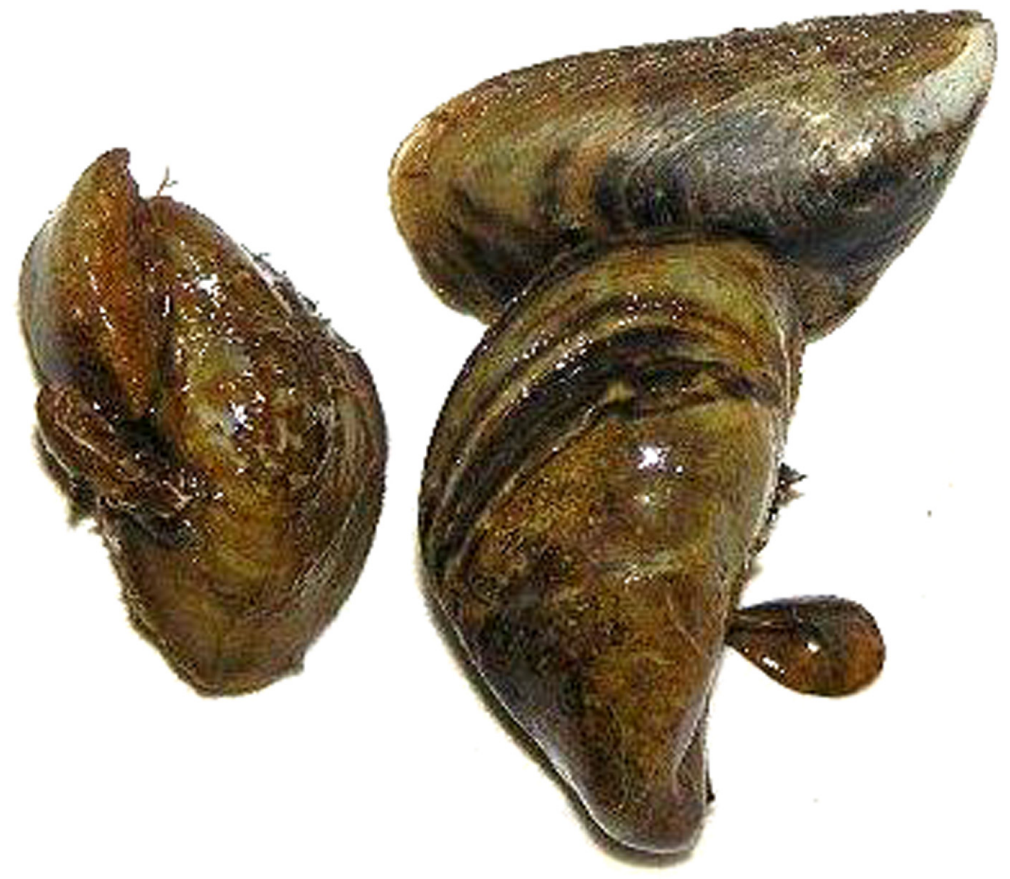

Fig. 2. Specimens of Dreissena bugensis from Romanian Danube (Photo O. Popa)

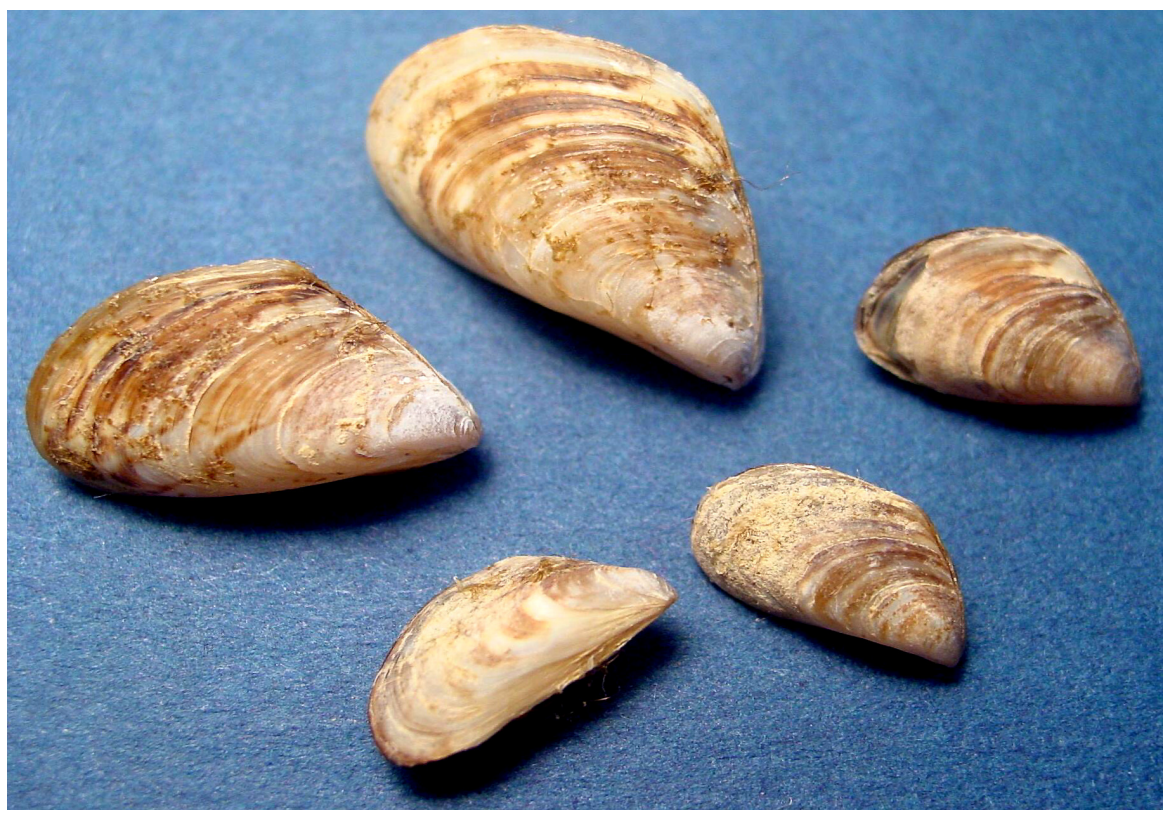

Fig. 3. Dreissena bugensis from Great Lakes, Nort America (Photo @USGS-NASbase) 